\title{
MĀORI WOMEN, DISCRIMINATION AND PAID WORK: THE NEED FOR AN INTERSECTIONAL APPROACH
}

\author{
Amanda Reilly*
}

\begin{abstract}
New Zealand has been at the forefront of labour regulation and views itself as a leader in the field of human rights. However, this article focuses on an area where the law is underdeveloped. It argues that the ongoing socio-economic inequality of Māori women is inconsistent with social justice, New Zealand's international human rights obligations and the Treaty of Waitangi. Improving access to paid work could help to address this, but the law does not adequately address the intersectional discrimination - discrimination on multiple grounds - that Māori women and others experience. New Zealand discrimination law, in both the human rights and employment jurisdictions, is largely comparator-based which is inherently flawed as a mechanism for addressing intersectional discrimination. Moreover, the law is poorly understood and weakly enforced. New Zealand also has limited affirmative action provisions; no quotas or targets are set with regards to improving the access to paid work of Māori women and very few New Zealand employers are required to report on matters pertaining to gender equality. The article concludes that the impact of intersectional discrimination on Māori women (and others) must be recognised and addressed and that a range of options is available to do this, if the political will were present.
\end{abstract}

\section{INTRODUCTION}

It is an established fact that Māori women are socio-economically worse off on a range of measures than women of other ethnicities. ${ }^{1}$ Māori women are particularly disadvantaged in employment, even relative to Māori men. For example, young Māori women under 25 have an unemployment rate of 23.6 per cent. ${ }^{2}$ More generally, Māori unemployment is twice as high as the

* Senior Lecturer, School of Accounting and Commercial Law, Victoria University of Wellington. I would like to thank and acknowledge Steve Hickey for helpful comments on an earlier draft of this article and Ashleigh Dale and William Townsend for their contributions as research assistants. I would also like to thank Professor Gordon Anderson for many years of mentorship, intellectual stimulation, support and friendship.

1 Ministry of Health "Socioeconomic indicators" (2 August 2018) <www.health.govt.nz>.

2 Human Rights Commission "Tracking Inequality at Work" (2015) <https://tracking-equality.hrc.co.nz>. 
rate for all other ethnic groups and proportionately, Māori workers have the highest incidence of work in temporary jobs and are exposed to higher levels of insecurity and precarity than workers of other ethnicities. ${ }^{3}$ Māori are also more likely to report experiencing discrimination in the workplace than Europeans. $^{4}$

As noted by Gordon Anderson, labour law plays a central role in protecting working peoples' access to the material conditions of life and the failure of law to protect the access of Māori women to this is troubling. ${ }^{5}$ Furthermore, art 3 of the Treaty of Waitangi affirms the principle of equality and non-discrimination between New Zealanders. ${ }^{6}$ The current disadvantaged socio-economic position of Māori women is inconsistent with this. ${ }^{7}$ New Zealand is also bound under various ratified international human rights instruments to improve the position of Māori and it has been noted on numerous occasions that New Zealand is not living up to these obligations. For example, the UN Committee on the Elimination of Racial Discrimination has recommended that New Zealand "should intensify efforts to improve the outcomes of ... Māori ... in the fields of employment, health and in the administration of criminal justice". ${ }^{8}$ The Special Rapporteur on the United Nations Declaration on the Rights of Indigenous People has commented that the most notable way in which New Zealand's obligations are not being met is "the extreme disadvantage in the social and economic conditions of Māori people in comparison to the rest of New Zealand society". ${ }^{9}$ The UN Committee on the Convention on Elimination of Discrimination Against Women has also identified the disadvantage of Māori women as problematic and has indicated there is reason to believe Māori women may be vulnerable to multiple forms of discrimination due to the intersections between their identities as

3 New Zealand Council of Trade Unions Under Pressure: A Detailed Report into Insecure Work in New Zealand (October 2013) at 26.

4 Statistics New Zealand Working together: Racial discrimination in New Zealand (10 September 2012) $<$ https://stats.govt.nz $>$ at 6 .

5 Gordon Anderson Labour Law in New Zealand (2nd ed, Wolters Kluwer, Alphen aan den Rijn (Netherlands), 2015) at 3.

6 The Māori text of the Treaty has been interpreted as entailing a more specifically Māori interpretation of citizenship than the Western understanding of citizenship as entailing equal rights. See generally Māmari Stephens "To Work Out Our Own Salvation: Māori Constitutionalism and the Quest for Welfare" (2015) 46 VUWLR 907 at 917-920. While important in constitutional terms, further discussion of this is beyond the scope of this article.

7 This is not a novel point. The Mana Wahine claim (Wai 381) submitted in 1993 to the Waitangi Tribunal alleges the Crown has discriminated against Māori women, depriving them of entitlements under the Treaty including to social and economic well-being.

8 United Nations Committee on the Elimination of Racial Discrimination Concluding observations on the 18th to 20th periodic reports of New Zealand (CERD/C/NZL/CO/18-20, 2013) at [15].

9 James Anaya Report of the Special Rapporteur on the rights of indigenous peoples, Addendum: The situation of Māori people in New Zealand UN Doc A/HRC/18/35/Add.4 (31 May 2011) at 2. 
women, as caregivers and as Māori. ${ }^{10}$ This is consistent with an extensive body of research which suggests that ethnic women are typically subject to multiple, intersecting forms of disadvantage in a range of settings. ${ }^{11}$

Mai Chen has called for New Zealand discrimination law to be comprehensively reformed to address intersectional discrimination. ${ }^{12}$ This article adopts an intersectional perspective to critically evaluate New Zealand's discrimination law, in the area of employment, with a focus on Māori women. Its central thesis is that the law does not adequately address the intersectional discrimination that Māori women may encounter in accessing and progressing in paid employment. ${ }^{13}$ It also discusses how the law might be reconfigured to better address intersectional discrimination.

This article focuses on Māori women because the Treaty, and other international obligations, add weight to the more general argument that New Zealand law does not adequately acknowledge or address intersectional discrimination in employment. However, there are other groups in New Zealand who are also marginalised in the labour market. Pacific women and the disabled are two notable examples. ${ }^{14}$ Broader recognition of the effects of intersectional discrimination for these groups (and others) as well as concerted effort to address this are also essential.

The article is divided into the following sections:

- $\quad$ Part II expands on the concepts of intersectional disadvantage and its implications for Māori women.

- Part III considers the law around discrimination in an employment context and suggests that, while it does not preclude intersectional claims, it could be strengthened.

- $\quad$ Part IV comments on the need for other measures and proposes some complementary or alternative mechanisms to litigation.

- $\quad$ Part V discusses the importance of adequate resourcing for the Human Rights Commission.

10 United Nations Committee on the Elimination of Discrimination against Women Concluding observations of the Committee on the Elimination of Discrimination against Women: New Zealand (CEDAW/C/NZL/CO/7, 2012) at 10.

11 See Mai Chen The Diversity Matrix: Updating What Diversity Means for Discrimination Laws in the 21st Century (Super Diversity Centre, 2017) at [4].

12 At [3].

13 I acknowledge, but cannot here address, the many persuasive feminist critiques of the unjustness of privileging paid employment over unpaid care work. See generally Martha Fineman The Autonomy Myth: A Theory of Dependency (New Press, New York, 2004); Nancy Fraser "After the Family Wage: Gender Equity and the Welfare State" (1994) 22 Political Theory 591; and Marilyn Waring If Women Counted: A New Feminist Economics (HarperCollins, New York, 1990).

14 Young Pacific women have an unemployment rate of 31.4 per cent and only 46 per cent of disabled women participate in the labour force: see Human Rights Commission, above n 2. 


\section{WHAT IS INTERSECTIONALITY AND HOW DOES IT IMPACT ON MĀORI WOMEN?}

\section{A Intersectionality}

Kimberle Crenshaw most influentially used the metaphor of an intersection to illustrate the complexity of the relationship between identity and the causes of subordination. ${ }^{15}$ She argued, in the context of the United States, an African-American woman's identity as a woman may intersect with her identity as an African-American. She may be discriminated against on either grounds or on both grounds cumulatively. Crenshaw's critique called for attention to the intersections of subordination.

Intersectional discrimination must be distinguished from discrimination on additive multiple unrelated grounds which is where there may be multiple grounds of discrimination but they do not overlap to cumulatively amount to more than the sum of their parts. An example of additive discrimination is the case of Wang $v$ New World Market Ltd where the Employment Relations Authority found there was discrimination on the basis of age and disability in relation to separate incidents. ${ }^{16}$ Age discrimination was found in the advertisement for an older worker. The finding of disability-based discrimination related to the discovery that the plaintiff had been diagnosed with Asperger's Syndrome following an incident where the plaintiff became extremely distressed.

This must be contrasted with intersectional discrimination which is where the discrimination experienced by the complainant cannot be broken down into component parts but rather is based on "a combination of different characteristics, which produces 'something unique and distinct from any one form of discrimination standing alone."'17 This is a more complex and difficult form of discrimination to recognise, prove and address, but it is the form of discrimination that is of present interest.

The idea of intersectional discrimination now forms part of mainstream discourse. ${ }^{18}$ It has been recognised across academic disciplines and considered in a variety of legal jurisdictions. ${ }^{19}$ Some feminist scholars have criticised the concept, suggesting that its focus on identity leads to a failure to

15 Kimberle Crenshaw "Demarginalizing the Intersection of Race and Sex: A Black Feminist Critique of Antidiscrimination Doctrine, Feminist Theory and Antiracist Politics" [1989] U Chi Legal F 139 at 139.

16 Wang $v$ New World Market Ltd [2016] NZERA Auckland 124.

17 Mary Eaton "Patently Confused: Complex Inequality and Canada v Mossop" (1994) 1 Rev Cons Stud 203 at 229, as cited in Chen, above n 11, at [14], n 12.

18 See Jessica Berget "My Feminism will be Intersectional or it Will be Bullshit!" The Douglas College Newspaper (online ed, British Columbia, 21 March 2017).

19 See Sumi Cho, Kimberlé Williams Crenshaw and Leslie McCall "Toward a Field of Intersectionality Studies: Theory, Applications, And Praxis" (2013) 38 Signs 785; and Ben Smith "Intersectional Discrimination and Substantive Equality: A Comparative and Theoretical Perspective" (2016) 16 The Equal Rights Review 73 at 88-98. 
address the processes which produce inequality. ${ }^{20}$ However, as noted by Sandra Fredman, law cannot address an injustice if the injustice is not identified; if there are "detrimental consequences attached to membership of a particular group", intersectionality provides us with a lens to see this so that we may design measures to address it. ${ }^{21}$

\section{B Impact of Intersectionality on Māori women}

Indigenous scholars from colonised nations, including Māori, have responded to the concept of intersectionality. ${ }^{22}$ Naomi Simmonds comments: ${ }^{23}$

[It is for Māori women to,] on our own terms and in our own way, (re)define and (re)present the multifarious stories and experiences of what it means, and what it meant in the past, to be a Māori woman in Aotearoa New Zealand.

Some have argued that the very language of human rights (which is the language used here) is alien to what it means to be an indigenous woman. ${ }^{24}$

Before proceeding, a disclaimer is necessary. This analysis is not an attempt to derogate from, or contribute to, the process of delineating what it means to be a Māori woman. That work belongs to others more qualified. ${ }^{25}$ The intention here is simply to note patterns of discrimination to contribute to an understanding of how law might be reconfigured to better address discrimination in employment.

With this disclaimer in place, Human Rights Commission data indicates that women are more likely to be discriminated against than men in New Zealand in relation to employment. ${ }^{26}$ Men receive higher pay than women overall. This is also true within ethnic groups. ${ }^{27}$ This is not the whole of the

20 Emily Grabnam and others (eds) Intersectionality and Beyond: Law, Power and the Politics of Location (Routledge-Cavendish, Abingdon-on-Thames (UK), 2009) at 77.

21 See Smith, above n 19, at 99, discussing Sandra Fredman "Positive Rights and Positive Duties: Addressing Intersectionality" in Dagmar Schiek and Victoria Chege (eds) European Union Non-Discrimination Law: Comparative Perspectives on Multidimensional Equality Law (Routledge-Cavendish, Abingdon-on-Thames (UK), 2009) 73 at 74.

22 See generally Naomi Simmonds "Mana Wahine: Decolonising Politics" (2011) 25(2) Women's Studies Journal 11. Simmonds herself discusses and develops the mana wahine approach which both theoretically and methodologically examines the intersection of being Māori and a woman.

23 At 23

24 See Kerensa Johnston "Discrimination, the State and Māori Women. An Analysis of International Human Rights Law and the Convention on the Elimination of all Forms of Discrimination Against Women" (2005) 8(2) YNZJ 31

25 Simmonds, above n 22.

26 Human Rights Commission, above n 2.

27 Human Rights Commission, above n 2. 
story for Māori women who, in common with indigenous women from other settler nations, ${ }^{28}$ have a distinctive cultural experience derived from history and the ongoing impact of colonisation. ${ }^{29}$

As noted by Te Kawehau Hoskins: ${ }^{30}$

Western feminist tradition has for a long time posited gender as the primary and universal site of oppression, while largely ignoring factors of class and race ... this position is untenable because it fails to expose/own/acknowledge not only white Pakeha women as beneficiaries of Māori women's dispossession through colonization but also their implication in these relations in a post-colonial Aotearoa. Our status as tangata whenua [first peoples] our culture and ... experience of colonization ... situates Māori women in a much larger reality that that of women's rights.

This is borne out by the fact that, in terms of employment, European women fare much better relative to Māori women. More European women are employed than Māori women. European women are more likely to be employed in higher skilled, higher paid positions than Māori women and earn more per hour than Māori women. European women are also more likely to earn in the highest quintile than Māori women. ${ }^{31}$

The causes of this may be complex but it seems likely that it is in part because Māori women encounter intersectional discrimination both as Māori and as women. It is also likely that some Māori women encounter discrimination as caregivers (i.e. on the basis of family responsibilities). ${ }^{32}$ There is a growing body of research that suggests mothers are often subject to additional discrimination through unconscious biases. This makes them less likely to be employed, less likely to be promoted, as well as held to higher standards. ${ }^{33}$ There is no reason to believe that New Zealanders are immune to this particular unconscious bias. It is possible that Māori women are more subject to this than others;

28 Carol Williams "Introduction" in Indigenous Women and Work: From Labor to Activism (University of Illinois Press, Illinois, 2012) 1 at 12.

29 See Ani Mikaere "Colonization and the destruction of gender balance in Aotearoa" (1999) 12 Native Studies Review 1; and Ani Mikaere "Māori Women: Caught in the Contradictions of Colonised Reality" (1994) 2 Waikato L Rev 125.

30 Te Kawehau Clea Hoskins "In the Interests of Māori Women? Discourses of Reclamation" in Alison Jones, Phyllis Heda and Tamasailau Suaalii Bitter Sweet: Indigenous Women in the Pacific (University of Otago Press, Otago, 2000) 33 at 43.

31 Mike Hensen and John Yeabsley Changes in Women's Earnings: Key Changes over the Last 30 Years and Comments on the Outlook for the Next 10 Years (Ministry of Women's Affairs, January 2013).

32 Of course, addressing discrimination law is not the only law change that could help Māori women and others with family responsibilities to access and retain employment. See further Amanda Reilly and Annick Masselot "Precarious Work and Work-Family Regulation: A Critical Evaluation of New Zealand's Regulatory Framework" (2017) 98 BCLR 285.

33 See Joan Williams and Nancy Segal "Beyond the Maternal Wall: Relief for Family Caregivers who are Discriminated Against on the Job" (2003) 26 Harv Women's LJ 77. 
the average number of children born per women by ethnicity is 1.83 for European women and 2.79 for Māori women. ${ }^{34}$ A recent Longitudinal Study of Ageing also indicated that Māori are more likely to provide family care for elders than other ethnic groups in New Zealand: 23 per cent of all Māori women compared to 16 per cent of New Zealand European women. ${ }^{35}$

To sum up, while individual experiences vary, the evidence above suggests that a Māori woman in New Zealand stands a greater chance of encountering discrimination in accessing paid work on a range of grounds flowing from intersecting factors: on the grounds of family responsibility, as a woman and as an individual of Māori ethnicity. This discrimination may be a result of individual unconscious bias or overt discrimination. This is not simply attributable to individuals as it is tied to systemic disadvantage stemming from historical factors.

Discrimination and inequitable access to paid work translate to low earnings and related socioeconomic disadvantage. One unfortunate consequence of this is that it brings more Māori women into contact with the welfare system. In June 2013, 43.3 per cent of those receiving Sole Parent Support were Māori women. ${ }^{36}$

The approach adopted by the New Zealand welfare system conforms to the pattern found in other countries, i.e. that of punitive welfare provision which stigmatises recipients. ${ }^{37}$ Beneficiaries who do not satisfactorily take part in required activities, for example if they miss appointments, are subject to financial sanctions in the form of punitive and harsh benefit reductions causing extreme hardship. ${ }^{38}$ There is also no shortage of accounts of the corrosive, damaging effect of the stigmatising discourse surrounding welfare, or of the contempt with which beneficiaries are often treated by the institutions supposed to serve them. ${ }^{39}$

34 Statistics New Zealand Fertility of New Zealand Women by Ethnicity: Based on New Zealand 1996 Census of Population and Dwellings (February 2004).

35 Fiona Alpass, Sally Keeling and Rachel Pond The New Zealand Longitudinal Study of Ageing: Caregiving (The Health and Ageing Research Team, School of Psychology, Massey University, The Family Centre Social Policy Research Unit and The Foundation for Research, Science and Technology, 2014).

36 Ministry of Women's Affairs E Tü Ake! Stand Tall and Proud: A Working Paper on Raising the Qualifications and Earnings of Low Income Women (March 2014).

37 See Beth Goldblatt "Gender, poverty and the development of the right to social security" (2014) 10 Int J L C 460.

38 Social Security Act 2018, ss 236-239, 244 and 253. For an account of the hardship resulting from these sanctions see Donna Wynd Benefit Sanctions: Children - not seen, not heard (Child Poverty Action Group, June 2014).

39 For example, Marriot's research indicates that those suspected of benefit fraud are far more actively prosecuted and even imprisoned than wealthy white collar tax evaders: Lisa Marriott "Tax crime and punishment in New Zealand" [2012] BTR 623. See also Welfare Justice: The Alternative Welfare Working Group Welfare Justice in New Zealand: What Ee Heard (Caritas Aotearoa New Zealand, November 2010); and a recent survey showed that more than half of beneficiaries are unhappy and feel the welfare systems is not supporting them 
In the lead up to the 2017 election, the Green Party campaigned on the abolishment of sanctions. However, in coalition negotiations, the party was forced to abandon this stance. ${ }^{40}$ Members of the Labour-led coalition Government have expressed concern about the culture of Work and Income and there has been a reduction in the number of benefit sanctions. ${ }^{41}$ Nonetheless sanctions have not been abolished and the Social Security Act 2018 states that: ${ }^{42}$

(a) work in paid employment offers the best opportunity for people to achieve social and economic well-being:

(b) the priority for people of working age should be to find and retain work ...

In other words, participation in paid work will continue to be the imperative underpinning the provision of welfare. While there may be some softening in terms of the punitiveness of the regime beneficiaries are subject to, it is not clear that this softening will be significant.

Carol Williams comments that historically, "[c]olonial self interest and other suspect motives allowed indigenous workers to be unregulated, underwaged ... and judgmentally scrutinized." 43 And it seems that, effectively, little has changed. More Māori women are in low wage and casualised work. ${ }^{44}$ More Māori women than women from other ethnicities are subject to a punitive and intrusive welfare regime with a focus on paid work as the path to inclusion. ${ }^{45}$ As a matter of social justice, it is imperative to address intersectional discrimination where it is operating as a factor preventing Māori women from accessing paid work. The question is whether New Zealand' law is up to the task.

\section{THE LAW IN NEW ZEALAND}

There is nothing in New Zealand law that would explicitly preclude a claim being brought for discrimination on intersecting grounds.

to find quality employment. Simon Collins "Winz told Pregnant Woman to Work as Beekeeper" The New Zealand Herald (online ed, Auckland, 10 August 2016).

40 Lloyd Burr "Greens back down on abolishing all benefit sanctions" (6 December 2017) Newshub $<$ www.newshub.co.nz >.

41 Isaac Davison "Government's 'kinder' approach to beneficiaries starting to show, as sanctions fall and hardship grants rise" The New Zealand Herald (online ed, Auckland, 19 July 2018).

42 This principles were originally set out in the Social Security Act 1964, s 1B(a)-(b) and were replicated in the Social Security Act, s 4(a)-(b)

43 Williams and Segal, above n 33, at 20.

44 Human Rights Commission, above $\mathrm{n} 2$.

45 Ministry of Social Development Prepared for the Welfare Advisory Group: Families and whanau and the benefit system - A high-level initial briefing (16 May 2018) at 4. 
The analysis above has suggested that Māori women may encounter intersectional discrimination as women, as Māori and on family status grounds. ${ }^{46}$ The New Zealand Bill of Rights Act 1990 establishes that "[e]veryone has the right to freedom from discrimination on the grounds of discrimination defined in s 21 of the Human Rights Act 1993", ${ }^{47}$ which include sex, ethnic origins and family status (which is defined as having responsibility for care of dependants). ${ }^{48}$

\section{A Intersectional Discrimination in Employment Law}

Although systemic long-term disadvantage plays out in a number of contexts, ${ }^{49}$ in an employment setting this disadvantage could manifest as discrimination in a range of ways including:

- $\quad$ a job applicant not being appointed;

- $\quad$ an employee being offered less favourable terms of employment or not being considered for promotion or deprived of access to other opportunities; and

- $\quad$ as a factor in a dismissal.

A Māori woman believing she had been discriminated against on intersecting grounds could make a complaint to the Human Rights Commission or file a personal grievance in the Employment Relations Authority. If this discrimination was experienced pre-employment she could complain under s 22(1)(a) of the Human Rights Act 1993. If she felt she had been disadvantaged in employment she could complain under either s 22(b) of the Human Rights Act or the Employment Relations Act $2000 . .^{50}$

Human Rights Commission data shows that there have been complaint made which rely on multiple grounds. ${ }^{51}$ A number of these complaints have been mediated although they have not progressed to the Human Rights Review Tribunal or the courts. Unfortunately, no equivalent data exists regarding complaints or mediated disputes in the employment jurisdiction. However, a review

46 Of course, depending on circumstance some individuals may encounter disadvantage on other grounds too.

47 New Zealand Bill of Rights Act 1990, s 19(1).

48 Human Rights Act 1993, s 21(1)(a), (g) and (l).

49 For example, Quince discusses how intersectional discrimination impacts upon the treatment of Māori women by police, judges and jurors in a criminal law setting. See Khylee Quince "Māori and the criminal justice system in New Zealand" in Julia Tolmie and Warren Brookbanks (eds) Criminal Justice in New Zealand (LexisNexis, Wellington, 2007) 333.

50 Section 105 of the Employment Relations Act 2000 replicates the prohibited grounds of discrimination set out in s 21(1) of the Human Rights Act. Under s 103(1)(c), employees are allowed to bring a personal grievance against an employer because of a claim that they have been discriminated against in the employee's employment. Such a claim arises if the employer disadvantages (s 104(1)(a)) or dismisses (s 104(1)(b)) an employee on any of the prohibited grounds.

51 Chen, above n 11, at [10]: "between October 2015 and October 2016, 15.4 per cent of complaints submitted to the HRC relied on more than one prohibited ground". 
of reported cases in the Employment Relations Authority between 2000-2017 revealed a few cases where multiple grounds of discrimination were alleged.

In most cases, the claims of discrimination were rejected on grounds of insufficient evidence, even if the claim was otherwise successful on other grounds. ${ }^{52}$ Only two cases alleging multiple grounds of discrimination were successful and neither addressed the issue of intersectional discrimination. ${ }^{53}$ In Wang, the discrimination claim was made on separate grounds relating to separate incidents. In the other successful case, Easterbrook $v$ Cycle and Carriage (City) Ltd, the discrimination was overt; the plaintiff was explicitly told she did not receive the promotion as she was not Asian and was not a man. Since it was explicitly stated that the promotion was denied on two of the prohibited grounds, discrimination was clearly established without any need for consideration of the nuance of whether this was a case of intersectional discrimination.

It seems clear that the possibility of a claim based on multiple grounds of discrimination is open in an employment law context and that such complaints have been made. Nonetheless, intersectional discrimination in employment has not been addressed by any New Zealand court and jurisprudence in this area is effectively non-existent.

\section{B The Need for Training}

Developing the jurisprudence would be an important step towards developing awareness of intersectional discrimination and ultimately towards reducing it, but this first requires that cases are brought. In one of the cases mentioned above the discrimination claims were rejected because they were not raised in the original statement of grievance. ${ }^{54}$ Without commenting on the particular merits of this case, it perhaps points to lack of knowledge among the general public of the possibility of claims on multiple grounds. Chen submits that as claimants do not appear to be expressly pleading intersectional discrimination, this suggests legal practitioners need training on identifying and bringing intersectional claims. ${ }^{55}$

52 Dent v Waikato District Health Board [2014] NZERA Auckland 526; George v Silver Fern Farms [2013] NZERA Christchurch 166; Shaw v Canterbury District Health Board [2014] NZERA Christchurch 532; Simonovski v Harvey Norman Stores (NZ) Pty Ltd ERA Auckland AEA 230/05, 13 October 2005; Pope v Māori Television Service ERA Auckland AA 417/04, 14 December 2004; Morrison v New Zealand First Internet Ltd t/a QQ Internet Cafe of Palmerston North ERA Palmerston North WEA 226/04, 3 August 2004; Merchant $v$ Shonit Kids World Ltd t/a Toyworld ERA Auckland AEA 105/04, 5 July 2004; and Jennings v Board of Trustees of Windy Ridge Primary School ERA Auckland AEA 206/01, 2 October 2001.

53 Wang, above n 16; and Easterbrook v Cycle and Carriage (City) Ltd WEA 3/01, 27 February 2001.

54 George, above n 52.

55 Chen, above $n$ 11, at [64]. 


\section{The Problem of the Comparator}

One potential impediment to claims being brought and the New Zealand courts fully embracing and addressing intersectional discrimination is the fact that New Zealand case law has established the use of a comparator, single axis approach. To succeed in a claim of discrimination, a complainant will have to show she has suffered a disadvantage as a result of one of the prohibited grounds or that it was a material ingredient in her treatment established by means of comparison with a notional other. ${ }^{56}$ As stated by Tipping $\mathrm{J}$ in Air New Zealand Ltd $v$ McAlister $:{ }^{57}$

\footnotetext{
Subject to any applicable statutory provision, the most natural and appropriate comparator is likely to be a person in exactly the same circumstances as the complainant but without the feature which is said to have been the prohibited.

In some circumstances the relevant legislative provisions will dictate how the comparator exercise should be undertaken. In the present case, under s 104(1)(a) for example, the comparison is between the circumstances of the complaining employee and those of other employees "in the same or substantially similar circumstances".
}

However, as has been addressed in literature elsewhere, a comparison-based approach is problematic when it comes to addressing intersecting grounds of discrimination such as ethnicity, gender and family status. ${ }^{58}$ A Māori woman would have to argue a distinct claim with regard to each legal identity because, as currently constructed, the law can only focus on one factor at a time. If she complains of discrimination as a woman, the obvious comparator is a man with the same qualifications and experience. As Māori, the comparator is an otherwise identical Pakeha. As a caregiver, the comparator is an otherwise identical person with no caregiving responsibilities. There is no comparator or scope for recognition of the cumulative disadvantage pertaining to the intersections of these identities.

\section{Potential Law Reform}

Bulllock and Masselot, writing in a European Union context, suggest that the notion of the comparator should be removed altogether from discrimination law as this inappropriately "etches an

56 Quilter v Attorney-General [1998] 1 NZLR 523 (CA) established disadvantage as comparison with a notional other. For an interesting discussion of problems with the lack of methodology for formulating comparators in New Zealand see Asher Gabriel Emmanuel "To Whom Will Ye Liken Me and Make Me Equal? Reformulating the Role of the Comparator in the Identification of Discrimination" (2014) 45 VUWLR 1.

57 Air New Zealand Ltd v McAlister [2009] NZSC 78, [2010] 1 NZLR 153 at [49] and [52].

58 Paola Ucellari "Multiple Discrimination: How Law can Reflect Reality" (2008) 1 The Equal Rights Review 24. 
ideal of the 'norm' into society's mind" which does not reflect the reality of human diversity. ${ }^{59}$ Everybody is comprised of a range of characteristics which may be advantageous or disadvantageous in different contexts. The idea that there is a norm from which difference is measured is limiting and it means that law cannot take account of social and historical context. ${ }^{60}$

Section 22(1)(a) of the Human Rights Act, relating to pre-employment discrimination, states that: ${ }^{61}$

Where an applicant for employment or an employee is qualified for work of any description, it shall be unlawful for an employer, or any person acting or purporting to act on behalf of an employer,-

(a) to refuse or omit to employ the applicant on work of that description which is available ...

Here, there is no explicit requirement to compare the applicant with another applicant (either real or hypothetical) to determine whether discrimination has occurred.

The courts have signalled that "New Zealand's human rights legislation ... is to be afforded a liberal and purposive interpretation, rather than an interpretation of a technical kind." 62 It would therefore be open to the courts to refer to a comparator in this situation.

By contrast, in s 22(2) of the Human Rights Act where an applicant or employee is offered less favourable terms of employment, the wording of the legislation explicitly requires comparison with other similar employees in determining whether or not discrimination has occurred.

There is merit in Chen's proposal that the law should be amended along the lines of the Canadian Human Rights Act to clarify that the New Zealand Human Rights Act encompasses both additive and intersectional claims. ${ }^{63}$ She proposes that s 21 of the Human Rights Act could have a new subsection inserted: "[f]or the avoidance of doubt, discrimination may be based on one or more of the prohibited grounds listed in subsection (1), and on a combination of prohibited grounds."64

59 Jess Bullock and Annick Masselot "Multiple Discrimination and Intersectional Disadvantages: Challenges and Opportunities in the European Union Legal Framework" (2013) 19 Colum J Eur L 57 at 74.

60 See Smith, above n 19, at 79.

61 Human Rights Act, s 22(1)(a).

62 Quilter, above n 56, at 575 per Tipping J.

63 Canadian Human Rights Act RSC 1985 c H-6.

64 Chen, above n 11, at [98]. 
Section 22(1)(b) of the Human Rights Act could be amended to make it possible to consider whether or not intersectional discrimination was a material factor in the disadvantage encountered, without reference to a hypothetical other, by means of a wording change along the following lines: ${ }^{65}$

(1) Where an applicant for employment or an employee is qualified for work of any description, it shall be unlawful for an employer, or any person acting or purporting to act on behalf of an employer,-

(b) to offer or afford the applicant or the employee less favourable terms of employment, ... than are made available to applicants or employees of the same or substantially similar capabilities employed in the same or substantially similar circumstances on work of that description ... [or based on any one of the prohibited grounds or combination of prohibited grounds].

This would mean the option to refer to a comparator would remain available where appropriate but it would not be a requirement

Whether or not these suggested reforms ultimately result in successful legal actions, amending the legislation to refer to the possibility of a combination of prohibited grounds would add to awareness of intersectional discrimination. As noted by Elisabeth MacDonald, human rights claims based on the prohibited discrimination grounds in the Human Rights Act have played an important role in activism in New Zealand. ${ }^{66}$

\section{THE NEED FOR OTHER MEASURES}

Raising awareness with a view to addressing the impact of intersectional discrimination on Māori women is essential. Changing the law to raise awareness and encourage litigation is one way this could be done.

However, while this would be symbolically significant and could result in incremental improvement, developing the law or even raising awareness through litigation is likely to be a slow and difficult process. Few cases in New Zealand proceed beyond mediation in either the human rights or employment institutions. This is unsurprising considering that the Human Rights Commission is required to use its best endeavours to assist the parties to achieve a settlement. ${ }^{67}$ The Employment

65 Employment Relations Act, s 104 could be similarly amended.

66 Elisabeth McDonald "Feminist legal theory in Aotearoa New Zealand: The impact of international critical work on local criminal law reform" (2014) 28(2) Women's Studies Journal 68 at 77.

67 Employment Relations Act, s 83(2). In 2015-16 the Human Rights Commission managed 1274 complaints of unlawful discrimination of which, only ten per cent of complaints were not resolved and were referred to the Human Rights Review Tribunal: Human Rights Commission and The Office of Human Rights Proceedings Annual Report: Pūrongo ā Tau 2016/2017 (November 2016) at 21. 
Relations Act objectives include "promoting mediation as the primary problem-solving mechanism" and consequently, mediation is the primary means of resolving employment disputes. ${ }^{68}$

Furthermore, according to Alysia Blackham, cases emerging in Australia suggest that strong discrimination claims are generally settled before court proceedings ${ }^{69}$ Even if the courts are willing to develop a jurisprudence around intersectional discrimination it will be hard to do this based on weaker claims. Unfortunately, although one cannot say for sure this would translate to a New Zealand context, there is research in the United States which suggests that intersectionality affects litigation outcomes; individuals from demographic groups affected by intersectional discrimination (i.e. nonwhite women) are least likely to win cases and plaintiffs who make intersectional claims are only half as likely to win their cases as other plaintiffs who make claims based on a single basis of discrimination. ${ }^{70}$

Moreover, discrimination law is a mechanism which has to be activated and negotiated at an individual level. Pursuing a discrimination claim requires a complainant to be aware of the discrimination and then to come forward and pursue a claim through a formal process which is likely to be long and difficult. Even if an individual succeeds in proving that an individual perpetrator is at fault, this may not provide for collective redress for structural and institutional inequality. This is particularly true if the victory is subject to confidentiality and is not widely publicised. As such, litigation is limited in its ability to effect systemic change in workplace cultures or to address collective discrimination or provide collective redress for structural and institutional inequality.

Other mechanisms to directly improve access to work for Māori women could complement the changes already recommended.

\section{A Extend Reporting Obligations}

Companies listed on the NZX Main Board stock exchange (excluding overseas companies) must include quantitative data in their annual reports on the gender breakdown of the directors and officers at the financial year end. ${ }^{71}$ This data must include comparative figures for the prior financial year end. ${ }^{72}$ Otherwise, New Zealand private sector employers are not required to report on gender equality at all. In contrast, New Zealand's public sector is subject to some reporting requirements. Core public

68 Employment Relations Act, 3(a); and Peter Franks "Employment mediation in New Zealand" (2003) 6 ADR Bulletin 1 at 1 .

69 Alysia Blackham "Recent Developments in Australian and New Zealand Age Discrimination Law: A Comparative Perspective" (2018) 43(2) NZJER 66 at 80.

70 Rachel Kahn Best and others "Multiple Disadvantages: An Empirical test of Intersectionality Theory in EEO Litigation" (2011) 45 Law \& Soc'y Rev 991.

71 NZX Limited Main Board/Debt Marking Listing Rules 2015, r 10.4.5(j).

72 Rule $10.4 \cdot 5(\mathrm{j})$. 
service organisations report to the State Services Commission on their gender pay gaps and the Commission publishes some limited information regarding this on their website. ${ }^{73}$ Crown entities who are subject to the good employer obligation are required to:

- $\quad$ make their good employer personnel policy (including the equal employment opportunities programme) available to their employees; ${ }^{74}$

- $\quad$ ensure their compliance with that policy (including its equal employment opportunities programme); and

- $\quad$ report in their annual reports on the extent of their compliance. ${ }^{75}$

The Human Rights Commission audits annual reports looking for references to equal employment opportunities programmes and these findings are reported on a website. ${ }^{76}$ A key limitation of this reporting requirement is that it simply requires a relatively small subset of New Zealand employers to have a policy and to report on their compliance with it. There is no requirement to provide detailed information which might point to patterns of intersectional disadvantage.

New Zealand could join other countries in extending reporting requirements if the political will were present. Countries such as Australia and the United Kingdom have implemented extensive gender equality reporting requirements. ${ }^{77}$ Information disclosure requirements could be designed to reveal patterns of intersectional discrimination.

A reporting requirement is a relatively modest recommendation which would raise awareness and force employers to confront inequality which they may not have been aware of. Employers could then take steps to address these inequalities, which would lead to positive behavioural change without further intervention from outside parties. ${ }^{78}$

Transparent, freely available data on gender and ethnicity would also make it easier for civil society to exert pressure on employers with regard to their employment practices. In the case of

73 State Services Commission "Public Service Workforce Data" (13 May 2019) <www.ssc.govt.nz>.

74 Crown Entities Act 2004, s 118(1)(b).

75 Crown Entities Act, s 118(1)(c).

76 Human Rights Commission "Crown Entities and the Good Employer: Annual Report Review 2007 to 2018 " (25 March 2019) <http://good-employer.hrc.co.nz>.

77 Workplace Gender Equality Act 2012 (Cth), s 13; and GOV.UK "Gender pay gap reporting: overview" (14 February 2019) <www.gov.uk>.

78 For more on the potential of reporting to drive change within organisations see Belinda Smith "How Might Information Bolster Anti-Discrimination Laws to Promote More Family-Friendly Workplaces? Encouraging and Enabling Compliance?" (2014) 56 JIR 547; and Belinda Smith and Monica Hayes "Using Data to Drive Gender Equality in Employment: More Power to the People?" (2015) 28 AJLL 191. 
intransigent employers, an improved reporting regime would also make legal actions easier as otherwise claimants are likely to struggle to find corroborating evidence. ${ }^{79}$

More ambitious steps are possible.

\section{B Quotas and Targets}

If the political will were present, employers could be required to take positive action, through quotas and targets, to further the employment of Māori women (or other disadvantaged groups) and to ensure that their needs are taken account of in the workplace. ${ }^{80}$ Such regulation avoids the issues associated with the individual complaints-based model and it is clear that this kind of action is not illegal under the New Zealand Bill of Rights 1990. ${ }^{81}$

The idea that quotas can be used to better the position of women in the workplace has been raised (and implemented) internationally and the possibility has also been mooted in the New Zealand context. ${ }^{82}$ Discussion has however largely been focused on elite women at the highest levels. Nevertheless, the potential of quotas is not limited to this demographic. Employers could be required to meet quotas of employees from disadvantaged groups through affirmative action programmes. In addition to creating a quota for Māori women, further specificity aimed at the most disadvantaged is also possible. Larissa Berendt stresses that it is important "to avoid the risk of elites within disadvantaged groups [taking] the majority of the fruits of the struggle for equality". ${ }^{83}$ Berendt suggests that one way to avoid this risk is by making ethnicity and gender the categorical basis of affirmative action programmes, then supplementing it with a quota which targets the most disadvantaged groups (for example the disabled).

In New Zealand, there are no quotas for women on company boards of directors. The furore over the Labour Party 2013 "man ban" proposal indicates some resistance to any suggestions of quotas for women among sectors of the New Zealand populace. ${ }^{84}$ If there is resistance to quotas which would

79 For further discussion on the importance of data see Ucellari, above n 58, at 41. See also Chen, above n 11, at [262].

80 See Fredman, above n 21, at 74 .

81 Section 19(2) states that "[m]easures taken in good faith for the purpose of assisting or advancing persons or groups of persons disadvantaged because of discrimination that is unlawful by virtue of Part 2 of the Human Rights Act do not constitute discrimination."

82 Judy McGregor "New Zealand's boardroom blues: time for quotas" 2014 28(2) Women's Studies Journal 4; and Annick Masselot and Timothy Brand "Diversity, quotas and compromise in the boardroom: tackling gender imbalance in economic decision-making" (2015) 26 NZULR 535.

83 Larissa Behrendt and Duncan Kennedy "Meeting at the Crossroads: Intersectionality, Affirmative Action and the Legacies of the Aborigines Protection Board" (1997) 4 AJHR 98.

84 "Labour/Greens fall behind as 'man ban' drives men to National - poll" The National Business Review (online ed, Auckland, 14 November 2013). 
benefit privileged women, it does not seem likely that a quota proposal to benefit disadvantaged women would be well-received even if justice and logic suggest that disadvantaged women need it most.

A more feasible outcomes-related mechanism may be to require employers to set and report on targets with regard to numbers of employees who meet specified criteria, such as being Māori and a woman. A target is a goal which the employer would set for themselves rather than an external requirement. Targets would allow for greater flexibility to take account of differences between employers of which there are many. For example, there are pronounced differences between sectors as well as geographic locations; employers in the rural South Island are in a different situation to employers in large cities.

Requiring private sector employers to set targets would be seen as a radical step in the current environment. Nonetheless, there exists some precedent as to how such a system might be designed. In South Africa, the Employment Equity Act 1988 requires designated employers (which includes employers who employ more than 50 employees), ${ }^{85}$ to put in place affirmative action measures to ensure equitable representation of people from designated groups in all occupational categories and levels in the workforce. ${ }^{86}$ Those measures must include numerical goals but exclude quotas. Employers must also set out a timeline for achieving their targets and indicate the strategies intended to achieve such targets. ${ }^{87}$

The Employment Equity Act was put in place in recognition of the historical legacy of apartheid and its creation of pronounced disadvantage of certain groups of people. Of course, New Zealand has its own unique cultural and historical context. However, Māori women still experience disadvantage stemming from the historical legacy of colonisation so it is worth considering what might be learned from the South African approach.

Requiring private sector employers to set targets with regard to the employment of Māori women might be seen as too radical an innovation. It is arguable however that the state, as an employer, has a greater obligation to address disadvantage encountered by Māori women in its own employment. The Crown is bound by art 3 of the Treaty of Waitangi which affirms the principle of equality and non-discrimination between New Zealanders.

85 Section 1.

86 Section 1 definition of "designated groups" means "black people, women and people with disabilities".

87 Section 20. 
State owned enterprises and Crown Entities are also bound by the "good employer obligation". ${ }^{88}$ This means that these organisations are required to operate an equal employment opportunities programme, ${ }^{89}$ which is defined as: ${ }^{90}$

... a programme that is aimed at the identification and elimination of all aspects of policies, procedures, and other institutional barriers that cause or perpetuate, or tend to cause or perpetuate, inequality in respect of the employment of any persons or group of persons.

This programme should recognise the special employment requirements of various groups such as Māori, women, ethnic minority groups and persons with disabilities. ${ }^{91}$ Implicitly this should include an awareness of the likelihood of intersectional discrimination.

At the present time, despite the specific and unambiguous directive inherent in these requirements, Māori women employed in the state sector are not faring particularly well. According to the Human Rights Commission "Tracking Equality At Work" tool, employment in the state sector reflects trends in the wider labour market. ${ }^{92}$ Male European public servants are the least marginalised group and earn more on average per annum, men are paid more within ethnic groups and the gap between European and Māori workers widened in $2015 .{ }^{93}$ It is encouraging to note the Government's "Gender Pay Principles" for the state sector announced in 2018 refers to the need to "achieve equitable outcomes for Māori women". ${ }^{94}$ This is in keeping with the recent concluding observations of the Committee on Economic, Social and Cultural Rights' recommendations: ${ }^{95}$

The Committee recommends that the State party introduce a government-wide strategy to ensure that the nature and impact of unconscious bias is understood by governance bodies and employees at all levels, due to the significant detrimental impact unconscious bias has on Māori in all areas of life.

However amending the relevant legislation to require these organisations to set targets to address such inequities would be a stronger commitment than a "statement of principles". At the very least, a legislative requirement to take account of the needs of Māori women which explicitly references the impact of intersectional disadvantage and discrimination, may be appropriate.

88 State-Owned Enterprises Act 1986, s 4(1)(b); and the Crown Entities Act, s 118(1)(a).

89 Crown Entities Act, s 118(3).

90 Crown Entities Act, s 188(3)

91 Crown Entities Act, s 118(2).

92 Human Rights Commission, above n 2.

93 Human Rights Commission, above n 2.

94 Ministry for Women "Gender Pay Principles" (1 April 2019) <https://women.govt.nz>.

95 United Nations Committee on Economic, Social and Cultural Rights Concluding Observations on the fourth periodic report of New Zealand UN Doc E/C.12/NZL/CO/4 (March 2018) at 3. 


\section{THE IMPORTANCE OF ADEQUATELY RESOURCING THE HUMAN RIGHTS COMMISSION}

One of the primary functions of the Human Rights Commission is "to advocate and promote respect for, and an understanding and appreciation of, human rights in New Zealand society". ${ }^{96}$ It is the obvious body to assume responsibility for raising awareness of the intersectional discrimination faced by Māori women and others. Possible options for the Commission include education and publicity campaigns and acting as an intervenor in relevant cases. ${ }^{97}$ However, if it is to effectively fulfil this role, the Human Rights Commission would need adequate resourcing, which it is not clear it currently has. ${ }^{98}$

The other suggestions above for addressing intersectional discrimination would also require additional resources. Any increase in reporting requirements would mean that additional funding would have to be made available to the Human Rights Commission or some equivalent entity to manage the auditing of the increased reporting requirement. The Human Rights Commission would also need additional powers to enforce compliance with reporting requirements.

If quotas or targets were to be introduced, the Human Rights Commission would have to have appropriate powers to monitor reporting as well as to sanction employers who repeatedly fail to meet targets. They would also need sufficient resources to extensively publicise breaches.

\section{CONCLUSION}

New Zealand prides itself on its reputation as a world leader in the area of human rights. However, this pride is misplaced when the issue of intersectional disadvantage is brought to the fore; New Zealand lags behind other similar jurisdictions in its recognition of the impact of intersectional disadvantage and in its jurisprudence in this area. New Zealand diversity initiatives largely focus on persuading employers of the business case for diversity, but this is a political choice. If the political will were present, a range of other options exists. The strategies for law reform described above could go some way towards addressing intersectional discrimination. They would also demonstrate an important symbolic commitment to the principles of equality, non-discrimination, social justice and respect for the individual dignity and human rights of workers.

96 Human Rights Act, s 5(1)(a).

97 See Chen, above n 11, at [151]. For further discussion on the possibilities here and for description of how the Ontario Human Rights Commission and Canadian Human Rights Tribunal have promoted a move towards an intersectional approach to discrimination.

98 Judy McGregor, Sylvia Bell and Margaret Wilson Human Rights in New Zealand: Emerging Faultlines (Bridget Williams Books, Auckland, 2016). 
